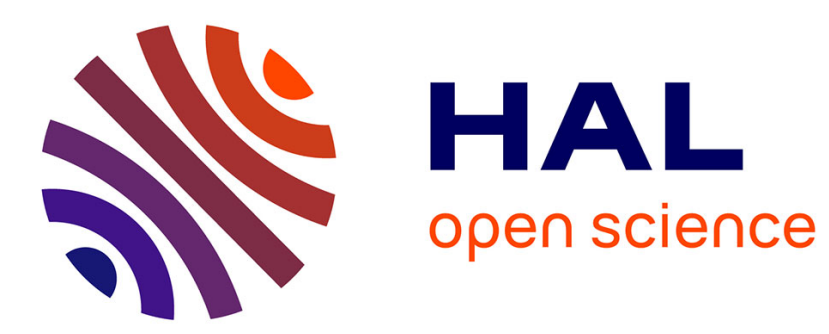

\title{
Segmented assimilation in the Netherlands? Young migrants and early school leaving
}

\author{
Willibrord De Graaf, Kaj Van Zenderen
}

\section{To cite this version:}

Willibrord De Graaf, Kaj Van Zenderen. Segmented assimilation in the Netherlands? Young migrants and early school leaving. Ethnic and Racial Studies, 2009, 32 (8), pp.1470-1488. 10.1080/01419870902763860 . hal-00521095

\section{HAL Id: hal-00521095 \\ https://hal.science/hal-00521095}

Submitted on 25 Sep 2010

HAL is a multi-disciplinary open access archive for the deposit and dissemination of scientific research documents, whether they are published or not. The documents may come from teaching and research institutions in France or abroad, or from public or private research centers.
L'archive ouverte pluridisciplinaire HAL, est destinée au dépôt et à la diffusion de documents scientifiques de niveau recherche, publiés ou non, émanant des établissements d'enseignement et de recherche français ou étrangers, des laboratoires publics ou privés. 


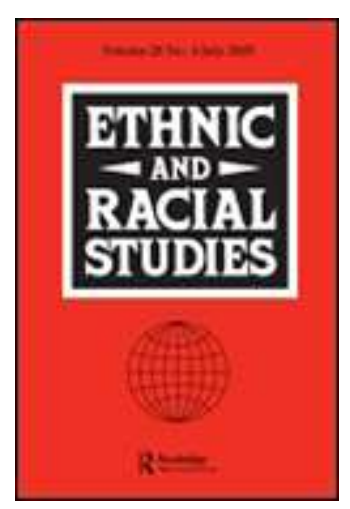

\section{Segmented assimilation in the Netherlands? Young migrants and early school leaving}

\begin{tabular}{|r|l|}
\hline Journal: & Ethnic and Racial Studies \\
\hline Manuscript ID: & RERS-2008-0180.R2 \\
\hline Manuscript Type: & Original Manuscript \\
\hline Keywords: & $\begin{array}{l}\text { Second Generation, segmented assimilation, migrant Youth, } \\
\text { ethnification, school dropout, unemployment }\end{array}$ \\
\hline
\end{tabular}

\section{s ScholarONE \\ Manuscript Central}


Table 1. Drop-out numbers, priority and total (x 1000)

\begin{tabular}{lcccccccc}
\hline & 98 & 99 & 00 & 01 & 02 & 03 & 04 & 05 \\
\hline Total new & 41 & 39 & 40 & 47 & 71 & 64 & 64 & 60 \\
Priority & 13 & 12 & 12 & 16 & 12 & $20^{1}$ & $16^{1}$ & $15^{1}$ \\
1new, before 2003 not possible to differentiate between old en new \\
Source: Sardes, 2006 (RMC data)
\end{tabular}


Table 2. Percentage priority drop out by ethnic background, 2005

$$
\text { priority drop-out remaining drop-out total drop-out }
$$

Ethnic origin:

\begin{tabular}{lccc} 
Dutch & 4 & 6 & 10 \\
Turk & 11 & 6 & 17 \\
Moroccan & 12 & 4 & 16 \\
Surinamese & 11 & 4 & 15 \\
Antillean & 14 & 9 & 23 \\
Other non-western & 11 & 4 & 15 \\
\hline
\end{tabular}

Source: Herweijer, 2006 
Segmented assimilation in the Netherlands? Young migrants and early school leaving.

\title{
Willibrord de Graaf, Kaj van Zenderen
}

\begin{abstract}
:
There has been ongoing debate in the Netherlands in recent years about secondgeneration immigrant youth, a debate fuelled by two, rather persistent phenomena: high school dropout and unemployment among migrant youth. Fear exists that migrant youth will become marginalized. This raises the question to what extent the position of migrant youth can be viewed as manifesting downward mobility, leading to a form of segmented assimilation? This article examines the problems of education and dropout, and discusses the significance of the many statistics which either prove or refute the assumed gravity of the problem. Then follows an outline of the policy landscape and the concomitant ethnifying effects to complete the picture. We conclude that downward segmented assimilation is not the dominant trend, and end with a discussion of new forms of ethnic exclusion that lay the blame for not integrating well into Dutch society at the foot of migrant youth themselves.
\end{abstract}

Keywords: segmented assimilation, school dropout, unemployment, second generation, migrant youth, ethnification 


\section{Introduction}

The position of non-western ${ }^{1}$ migrants in the educational system and on the labour market is generally not very favourable. This is a pattern that can be seen throughout Europe, and also in the Netherlands. Young migrants ${ }^{2}$ in particular, i.e. second generation migrants, often leave school early and risk exclusion from the labour market and society at large. There are several reasons for this state of affairs, such as shifts in the qualification structure for entering the labour market as a result of the emerging service and knowledge society; difficulties with raising the schooling levels of migrants; the existence of segregated neighbourhoods; problems of discrimination in the labour market itself; and ineffective search strategies by migrants on the labour market. All these factors are covered in the theoretical debate about the integration process of second generation migrants and the possible outcomes thereof. This debate has been fuelled by the observation that the supposed steady, gradual integration and acculturation into the host society was not taking place (Portes and Zhou, 1993). Instead, two different pathways seemed to emerge: first the diametrically opposed route into poverty and slipping into the underclass; and secondly, economic integration all the while maintaining cultural values and social commitments, in which case support from one's own social networks helps overcome obstacles to upward mobility (Zhou, 1997). Based on experiences in the USA in the first half of the twentieth century, the classical idea is that a gradual process of assimilation generally prevails. Some studies claim that this classical pattern can still be observed today (Perlmann and Waldinger, 1997). However, others

\footnotetext{
${ }^{1}$ The term 'non-western' refers here to its application in the Netherlands. Non-western means people from outside the EU, such as Asia, Africa, South America.

${ }^{2}$ The term 'young migrant' refers to the children of migrants (the second generation), born in the Netherlands.
} 
stress that changes in the structure of the labour market, institutional discrimination, and the living conditions in inner cities in particular mean that the classical pattern is now outmoded. They point out that the downward route was more prevalent among migrants following the Second World War (Portes, Fernandez-Kelly, Haller, 2005). The empirical results, both in the USA and Europe, show a mixed and contradictory picture (Thomson and Crul, 2007, Silberman, Alba, Fournier, 2007), which may be the result of different national contexts. This mixed picture applies also to the young migrants in the Netherlands: their overall situation is improving and more and more young migrants are faring well (CBS, 2008), but on the other hand there are groups that are not doing well, might be considered to be marginalized and are even ending up in criminality. This raises the question as to whether segmented assimilation exists in the Netherlands and can a tendency towards downward mobility be observed? The answer to this question is important since the public and political debate about the integration of migrants has been shifting to the conclusion that integration has been a failure and that more pressing measures have to be taken (WRR, 2007, Roggeband and Vliegenhart, 2007). Also internationally this shift in the Netherlands has been remarked and so it seems relevant to look into the specific Dutch national context in order to disentangle this complex matter of integration.

This article answers these questions by examining early school leaving among young migrants, also because dropping-out is seen as a marker for downward mobility in the discussion on segmented assimilation. The Dutch case is particularly interesting because, with a rate of almost 13 per cent of Dutch youth leaving school with less than upper secondary education, the Netherlands is below the EU average but above that of neighbouring European countries (OECD, 2008). Since this figure is barely diminishing, the OECD warns for long lasting unemployment which results 
from dropping-out and points to a group of marginalised, often migrant youth, who are detached from the labour market. Dropping out of school is also seen in the Netherlands as a disaster, and it is something that must be combated (WRR, 2008).

Because migrant youth are overrepresented in the dropout figures, the resulting 'moral panic' tends to see all migrant youth as being highly problematic and in danger of not participating in society. In fact, dropping out by migrants is seen as prove of their failure to integrate. And this in itself may contribute towards further ethnic stigmatisation and exclusion of young migrants. It is therefore very important that the problems in the transition from school to work be analysed, and similarly, that the effect the interpretation of these problems has on the position of migrant youth in general be examined.

There are two steps to our argument. The first step takes a look at a number of general findings about the educational position of young migrants and then analyses the existing data on dropout in the context of the transition from school to work. Our analysis shows that dropout rates are difficult to establish and may be used to both confirm and contradict the thesis of downward segmented assimilation. Moreover, there is no simple connection between dropping-out and success on the labour market. There are many different types of dropouts whose employment success differs. We point out how the discourses surrounding the supposedly problematic status of migrant dropouts may lead to their being blamed for their own disadvantage and failure to adapt successfully to the educational system.

In the second step we indicate more precisely how the context of policies, measures and reforms influences the educational situation of young migrants. We discuss the reforms in vocational education, the measures put in place to prevent migrants dropping out and to reintegrate dropouts, and how these arrangements are 
monitored and managed. We also attempt to show how this policy context contributes to the discursive representation of all migrant youth as a problematic group.

\section{Overall data on migrant youth in education}

The ethnic diversity of migrant groups in the Netherlands is considerable. In addition to the four main migrant groups: Moroccans, Turks, Surinamese, and Antilleans, there are also immigrant groups from Africa, Eastern Europe and Asia. It is beyond the scope of this paper to examine all these groups in detail, so we concentrate here on general patterns found among the youth of the four main migrant groups. The general socio-economic picture of these migrant youth in Dutch society is unfavourable. Compared with their native counterparts, most migrant youngsters are disadvantaged when it comes to education and work. They are less highly educated, have higher school dropout rates, unemployment levels are also greater, and their position on the labour market tends to be vulnerable (SCP/WODC/CBS, 2005). But when the socio-economic status of parents is taken into account, there are no big differences compared with native Dutch youngsters with the same background. Therefore, the position of migrant youth may largely be explained by the low educational and professional levels of their parents. But we will also show how policies actually reproduce the effects that they are intended to combat.

\section{Educational level and dropout}

There is a gap between the educational performance level of migrants and their native counterparts (Min. OCW, 2006). Migrant youth leave primary school at a 
considerable disadvantage i.e. some 1-2 years behind their native counterparts in language and maths. This means that they generally end up in lower vocational education, and migrant youth tend to follow the lowest streams of training courses (SCP/WODC/CBS, 2005). Of special concern are migrant school dropouts because they are overrepresented in the dropout rates: the percentage of migrant dropouts is almost twice as high: 9 per cent of the 18-24 age group compared with 5 per cent of the natives (CBS, 2007a, Min. OCW, 2007b). Despite this lower educational position, the trend for the educational performance of young migrants is positive. Their educational disadvantage has diminished over the past 15 years (SCP/WODC/CBS, 2005) and the performance level of second generation migrants is now closer to that of their native counterparts. The proportion of young migrants with the basic qualifications required for the labour market is on the increase, from 34 per cent between 2001 and 2003 to 43 per cent between 2004 and 2006 (CBS, 2007b). The proportion of migrants in higher education has increased substantially over the past five years (RWI, 2006) and successful migrants are increasingly seen as role models in the public sphere. Despite the general lower educational levels and higher dropout rates, migrants are making up for their deficit (SCP, 2007b). But this is a statement based on averages. It is important to note that there seems to be a divide between successful young migrants, who, in a roundabout way, end up in higher education or who have found a solid position in the labour market, and migrants who neither finish their education nor find suitable, regular jobs. There is, for instance, an increasing group of young people who do not attend school and who are not active jobseekers, 52,000 in 2004, and in 2005 this figure was 59,000 youngsters. This corresponds to 14 per cent of the native young people in the 15-22 age group and 32 per cent of migrant youth in this age group (Min. SZW, 2006). The 


\section{Transition from school to work and early school leaving}

The problem of early school leaving is, in the Netherlands, generally considered to have negative consequences for young people's labour market opportunities. The present discussion about the problematic transition from school to work actually began over thirty years ago when there were complaints about the lack of quality in the labour force, due to insufficient education, in relation to the promoted mobility and flexibility of workers. In 1990, a governmental advisory committee on the education-market relationship, the Rauwenhoff committee, promoted more equal participation in school and the establishment of a basic qualification that would guarantee access to the labour market and further vocational training (Houtkoop, 2004). "Investing in the schooling of unskilled workers clearly represents something of a threshold. The risk of not doing so however is that employees will be insufficiently mobile and flexible in the later stages of their working lives and so will be forced to drop out of the labour market prematurely" (cited in Houtkoop, 2004). The committee's proposals for a basic qualification were adopted by the government, thereby accepting the idea that a basic qualification focused on the problem of leaving school prematurely, because a minimum of vocational training was seen as a 
necessary condition for career development. Furthermore, this basic qualification was not only defined in educational terms, but also in terms of the personal and social skills required to participate in society.

The basic qualification involved completing at least the second level of secondary vocational education. Without a basic qualification, securing work is assumed to be difficult. This is why the definition of 'dropouts' in the Netherlands actually refers to all those who do not obtain this basic qualification. In fact, one is considered to be a dropout even with a certificate at the level of primary vocational education.

The dropout problem is high on the political agenda, because school dropouts are assumed to run a greater risk of being unemployed or of holding less favourable positions on the labour market, of having a low income, and of being jobseekers much longer than people with a basic qualification (Min. OCW, 2002). The discussion is further strongly influenced by the Lisbon agreements to halve the number of dropouts in the 18-24 age range between 2000 and 2010, and the national goal to reduce the number of new dropouts in the 12-22 age group by 50 per cent between 2002 and 2012 (Min. OCW, 2007a). What all these debates have in common is that dropping out is seen as a problem to be solved, while, at the same time, the extent of the problem remains unclear. We now go on to analyse the existing data on dropouts and show that the very nature of the data leaves little room for one simple interpretation.

\section{Registration, number and characteristics of dropouts}

Concern about dropout levels has led to a considerable amount of research being conducted with the primary aim of ascertaining the exact number of dropouts. 
However, measuring and registering school dropout numbers meet with numerous difficulties, and there are in fact no reliable figures available (Eimers, 2006). There are a number of reasons for this.

Firstly, measurements are partly based on incomplete data. The Netherlands has, since 1994, been divided into Regional Report and Coordination Points (RMC regions) to facilitate tackling the problem of school dropouts. Their task is to register the number of dropouts, and to ensure that dropouts do go on to obtain a basic qualification by taking the appropriate measures. Schools are obliged to report their dropouts to the RMC, but they do not report accurately and consistently, simply because, should they do so, they run the risk of getting a bad reputation. The RMCs admit that their registration method is not up to scratch and that they are unable to provide definite numbers (Sardes, 2006). However, the RMC figures indicate the number of new dropouts in the 12 to 22 age range every school year. In 2006 there were 56,000 new dropouts (Min. OCW, 2007a) comprising 35 per cent migrant youth. But the problem is that the figures do not take account of pupil mobilitysome pupils may return to school in the same school year. These registration problems could therefore mean that the number of dropouts is either underestimated or even overestimated (CPB, 2006).

A second point is that there are numerous different definitions of school dropouts, and many different methods to record measurement and timing. Dropouts are generally defined as young people in the 12 to 22 age range who have not attended vocational education for more than four weeks and who do not have a basic qualification. However, different studies apply different definitions, and this, in turn, leads to differing figures. For instance, besides the RMC, the CBS (Statistics Netherlands) provides figures on dropout rates based on the data from the Employed 
Population Survey (EBB), which is taken from a sample of the working population. The EBB data are used to present the Dutch dropout figures to the European Union, but they only pertain to the 18-24 age range. In 2006 the percentage of youth without a basic qualification and not attending school compared with the total number of young people in this age category of $18-24$ is 12.9 percent, which amounts to some 175,000 young people (SCP, 2007a). This number includes both new and old dropouts.

A new, third measurement method based on the educational number (ON) was introduced recently. This number identifies every individual participating in education and makes it possible to follow students throughout their entire educational career. The educational number measures the net number of dropouts in a school year. With this number, for the very first time, school dropout rates could be measured more accurately (Min. OCW, 2007b). The ON registration system indicates that there were 57,000 new dropouts in 2006 . This figure is close to the RMC figures, which could imply that the flaws in the RMC figures have been gradually corrected and/or that the $\mathrm{ON}$ registration is also still lacking.

\footnotetext{
Although the figures differ according to the sources used, it is possible to get an idea of the personal profile of dropouts. There are more males than females (60-40 per cent), while their share in the young age groups is more or less equal. The dropout rate is highest in the category $17-18$ years of age and most (67 per cent) are from secondary vocational education, and in particular from the first and second levels, intended to be the criterion for the basic qualification! Dropouts are already behind in their school career. Dropout rates are highest in regions where incomes are low, where there are more people on benefit, and where there are higher numbers of
} 
migrants. The chance of dropping out is twice as high in urban areas than in other areas, and this is particularly apparent in urban neighbourhoods characterised by poverty, segregation and poor housing (Min. OCW, 2007a). Furthermore, family circumstances i.e. being in a one-parent household or even being a parent, seem to influence higher dropout rates. In addition to the above characteristics, several analysts have also taken the efforts to define exactly which groups of dropouts are at high risk of non-participation - not working, not attending school.

Firstly, Sardes, the monitoring institution of the RMC figures, distinguishes pupils with a primary vocational certificate with other youngsters without any certificate at all, who are referred to as 'priority' dropouts (table 1). (table 1 about here)

The proportion of young migrants in the total of new dropouts was about 41 per cent in 2004 and 35 per cent in 2005, a figure which is still disproportionately higher than their share in the age group, but a decline has been observed. However, the picture for migrants looks less positive if we consider their share in the priority group. Other findings indicate that the young migrants in the priority group in particular are overrepresented (table 2).

(table 2 about here)

Secondly, Eimers, generally seen as an expert on Dutch school leaving, makes a distinction between school leavers at risk and non-problematic school leavers School leavers at risk are confronted with problems both at school and outside it, which make it difficult for them to perform well or even attend school. Some of them are not capable of obtaining a basic qualification. This group amounts to 25,000 , and this figure seems to be relatively stable. The non-problematic dropouts consist of 35,000 early school leavers, but they often do have a diploma at primary 
vocational level, have a job or do not want to work or cannot work because they have care responsibilities (Eimers, 2006).

Thirdly, there is a link between not having a basic qualification, being unemployed and/or not willing to work, and not being registered in the Public Employment Service. Non-registration would imply that this group is difficult to locate and approach through the official channels. This group is estimated to be around 38,000, a figure that crops up at times to refer to hard core problematic youth and also points at migrant youth as having a disproportionate share. This is the outcome of calculations made by the Taskforce Youth Unemployment (Taskforce Jeugdwerkloosheid, 2006)

Fourthly, when assessing which dropouts are most at risk it is also possible to focus on the long-term unemployed, i.e. those who have been unemployed for over half a year. A survey among second generation Turks and Moroccans in Amsterdam and Rotterdam showed that this group is relatively small with only 9 per cent falling into this category (Crul et al.2008), and the remainder had been unemployed only for a couple months.

These examples of high risk dropouts make it clear that different criteria are used and consequently different numbers emerge. Furthermore, it is still unclear what exactly their 'problematic' status is. But whatever the criteria used, the at-risk groups are surprisingly small. However, in the debate surrounding early school leaving it is these groups that are placed at the forefront and are used to point to the grave nature of the problem. What we learn from these data is that some groups may, indeed, be cause for concern even though the criteria for belonging to these groups are not well defined. The problems about registration, definitions and groups-at-risk clearly 
indicate that what is needed is a more refined analysis of what these figures mean and of how they are interpreted and used in the context of the debate on school dropout levels. This would help assess the migrant proportion of dropout levels and the tendency to downward or upward mobility of young migrants. We will show that there are a number of different ways of looking at and interpreting these figures and of assessing the extent of the problem. By doing so the problem of early school leaving can either be overestimated or underestimated.

\section{Overestimation of the problem}

The discussions and concerns about the persistent 'high' dropout rate imply that there is a big problem, particularly in relation to future labour market prospects. But the question remains about the extent to which the lack of a basic qualification is a real problem in the transition from school to work. Research findings suggest that a basic qualification is not necessarily essential when looking for work. Many of the dropouts are, in fact, employed. At least 65 per cent of the total group of dropouts aged between 15 and 22 do have a job, and three quarters of this group have a permanent contract (Min. OCW, 2007a). Many young dropouts with only a basic pre-vocational certificate do participate in the labour market (71 per cent), while the employment rate for youngsters with a basic qualification is 81 per cent. These data do not indicate that the lack of a basic qualification is a major obstacle on the labour market.

According to the Educational Council (Onderwijsraad, 2004), the basic qualification is not a critical boundary per se for success on the labour market. It is even stated that using the basic qualification in this way means that many youngsters are stigmatised. Generally, the effect of qualification is more of a sliding scale: the 
more highly qualified, the better one's chances on the labour market (CPB, 2006). The basic qualification should therefore be seen as an educational level that offers opportunities on the labour market but it does not necessarily mean that young people without a basic qualification do not have any prospects. This was recently confirmed by a survey among second generation Turkish and Moroccan youth in Amsterdam and Rotterdam. A quarter of these youngsters, who left school without obtaining a basic qualification, are considered to be at risk. However, the majority of men who are supposedly at risk are easily employed once they leave school and are only unemployed for a couple months. These findings confirm the fact that the labour market clearly has an integrative role for many of these youngsters (Crul et al., 2008).

To avoid overestimating the problem of early school leaving in relation to successful entry into the labour market, it is therefore necessary to analyse more precisely the characteristics of the group without a basic qualification. Several studies show that dropouts are not a homogenous group, and they can be divided into different categories with different statuses and different dynamics on the labour market. The above-mentioned description of the various at-risk groups is already one way to point to differentiated factors involved in dropping out.

However, other factors are also at play. Some students may not be capable of obtaining a basic qualification because of a lack of aptitude or as a result of their social circumstances (CPB, 2006), and they will also have difficulties on the labour market. Dropping out for other students depends on a combination of push and pull factors. For instance, an important pull factor is what is referred to as 'green picking' (RWI, 2005), which means that employers hire students shortly before they finish their formal education and obtain a basic qualification. This is often the case when 
students are in work placement and are offered a contract. The effect of green picking recently curbed the decline in the dropout rate and caught the attention of the government. Many vacancies became available because of the current positive economic situation and young people are encouraged to leave school and to work (Min. OCW, 2008). However, this clearly depends on the economic situation: when labour market opportunities are tight, pull factors may become push factors; see the following section.

A final important question is how dropouts see their qualifications in respect of their situation on the labour market. The little research that has been conducted on this issue seems to indicate that many dropouts enjoy gainful employment and do not consider themselves to be a problem (Lee and Breen, 2007, Dekkers and Claassen, 2001). Work seems more rewarding for them because it gives them money, respect, freedom, independence and responsibility. Qualitative research in the Netherlands on a group of dropouts confirms that the majority of youngsters were, in fact, satisfied with their current situation and did not particularly regret leaving school early. Those with a job seemed to have got used to their income level (Portengen and Dekkers, 1998). The dominant discourse in which dropouts are constructed as unsuccessful and problematic is, according to the dropouts themselves, clearly false (Lee \& Breen, 2007).

\section{Underestimation of the problem}

But it is also possible to construe the argument that the dropout problem is actually underestimated. This argument starts with how the dropout rate is calculated. This rate is determined each year by counting the number of new dropouts. All the old dropouts from previous years are therefore excluded from these figures, and this 
makes a considerable difference in the reported dropout rate. According to the RMC data, there were almost 57,000 registered new dropouts in the 2004-2005 school year, but there were also 45,500 registered old dropouts who did not return to school, so this amounts to a total of 102,500 dropouts.

Another problem is that the dropout rate, however it is calculated, is on the decrease, but it is a slight decline, and not sufficient to meet the European target, which is to halve the total number of new dropouts since 2000, which means reaching a figure of 35,000 in 2010 (Min. OCW, 2007b). This would indicate that the problem is rather persistent and difficult to combat, particularly if the target figures were to include the old dropouts.

Furthermore, attention should be given to the fact that the relationship between the basic qualification and labour market positions is strongly mediated by economic cycles. When the economic climate deteriorates, the employment opportunities for young people without a basic qualification diminish rapidly (RWI, 2006, Taskforce Jeugdwerkloosheid, 2006). Young people without a basic qualification tend to have jobs in the lower segments of the labour market, which makes it easier for employers to fire them. Dropouts are therefore the first to lose their job, and they have less chance of sustainable labour participation (RWI, 2006; Taskforce Jeugdwerkloosheid, 2006).

These discussions about underestimating or overestimating the problem of dropout are important because they point to the dynamics involved in the transition from school to work. As we have shown, the number of dropouts is related to economic developments, to low educational levels and low socio-economic status, and to personal and social problems. Furthermore, this discussion must not preclude 


\section{Policies on the transition from school to work}

Although there are projects and measures in place to help migrant youth into work, there is no formal education or labour market policy for specific groups. The problems of migrant youngsters in school are tackled from the angle of compensatory policies or of achieving the basic qualification, and unemployment of young migrants is combated within the general framework of enhancing labour participation for young people. Therefore, the policies pertaining to the school-work transition for migrant youth are mostly described as part of more general measures and proposals. But at the same time it has to be acknowledged that in these policies the explicit or implicit referral to migrants has always the function to stress the urgency of the problem, as if it is primary a migrant problem .Especially in the debate about dropping-out the focus is on migrant youth as the group 'in danger' whereas the positive outcomes of their increasing successful participation in education and labour are underexposed. 


\section{Vocational education and basic qualification}

The norm of the basic qualification stemmed from a major reform of vocational education in 1996. The reform aimed at flexible and individualised learning paths, at reducing the dropout level, and at a greater influence of the business community on content. The new system of (pre)vocational education entailed more theoretical elements which made it more difficult for groups of pupils to get a diploma, which led to a higher number of 'early school leavers'. So, paradoxically, the reform that aimed, amongst other things, to combat dropout, had, in fact, the opposite effect.

This sparked a fierce debate about the efficacy of the reform. Criticism of the resultant too theoretical level and the static content have led to plans for new attainment targets and new forms of teaching in vocational education. These plans have been developed with the approval of the business community, and are also considered to meet the needs of migrant youth (see SER, 2006). In a nutshell, attainment levels are now defined in terms of competences, both professional and social: i.e. the 'hard' and 'soft' skills. Students must learn these competences through what is referred to as 'new learning', which assumes that students work individually and in project groups on learning objectives, with teachers as coaches. But finding satisfactory translations of generally formulated competences into specific and testable skills is a problem, and both pupils and teachers feel that the move towards self-governed learning does not truly support the learning process. Preparations have started, but the difficulties encountered along the way have proved to be considerable (for a debate see Van der Werf, 2006, Stevens, 2006). These problems have given rise to a social debate about the dangers of new learning, and although the concept has not yet been abandoned altogether, the government decided in 2007 to postpone the introduction of the reform, planned for 2008, by at least one year. The 
educational concept of new learning is deemed to be detrimental to migrant youth in particular, because their cultural background does not prepare them for the selfguidance required. These concerns also indicate a shift in the construction of migrant youth as a problematic group.

Related to the discussion about the best way to set up vocational education, the compulsory age for being in education has become the focus of debate. In 1969 the compulsory school age was prescribed as being the end of the school year in which the pupil reached 16 years of age, followed by a year of part-time compulsory education. Compulsory school attendance ends at the age of 17. In practice, checking the part-time compulsory age proved to be difficult and many 16-17 year old pupils left education early without a basic qualification. This state of affairs was behind proposals to extend the school leaving age. As of 1-8-2007 the Compulsory Education Act has been extended with a 'qualification obligation' (Min. OCW, 2007b). This implies that all youngsters between 16 and 18 years of age who do not have a basic qualification are obliged to attend school full time in order to obtain this basic qualification.

This is seen as a first step. The plan is to extend the compulsory age to 23 , and possibly even to 27 . The focus in this period is on combining school and work. But other, more drastic plans have also been put forward, with the aim of forcing 'unwilling youth' into prep camps or boarding schools, the so-called campus approach, where they would be taught discipline, and again find the motivation to participate in society. How the coercive nature of this plan would be regulated within the existing legal framework is still not clear. Experiments based on voluntary participation are currently taking place (Taskforce Jeugdwerkloosheid, 2006; Min. Algemene Zaken, 2007). The main target for these plans are generally young 
migrants who are seen as troublemakers on the streets because of their lack of education and work and their resistance to being 're-educated' by social work and/or training.

\section{Combating dropout and youth unemployment}

Describing all the measures, projects, and taskforces that have been put in place to combat dropout and unemployment is beyond the scope of this article. We will, instead, present a brief overview of the three categories of underlying strategies. The first category is the strategy of supervision and obligation. Several routes are possible: one is refined registration and control, which means that young people without a basic qualification can be traced and returned to education or work experience programmes. When young people are past the compulsory school age (now 18), this can only be done on a voluntary basis. So extending the compulsory school age is a means to end this situation. Another way of forcing young people into work (and training) is, when they apply for social assistance, to refuse benefit and oblige them to work instead, i.e. the 'work first' approach. Proposals to send problematic youngsters to prep camps or boarding schools also fall into this category (Berenschot, 2006).

The second strategy involves creating training posts, work experience placement, jobs etc.. This is done by agreements between the social partners (government, employers and trade unions), municipalities and other involved players. These agreements are sometimes supported by measures such as wage subsidies or employers being exempt from having to pay certain social security contributions, or extra budgets for municipalities. In particular, the measures and projects in the second strategy are generally short term, local in nature, and have 
hardly been evaluated at all. The same activities are sometimes undertaken under new names.

The third strategy is the reform of vocational education, concentrating on a better rapport with the labour market through training positions, the development of professional and social (employee) skills as attainment levels, and flexible programmes. However, implementing these reforms is proving to be very difficult, and they meet with serious opposition from some quarters, including teachers, political parties, and students. Another development is to introduce the concept of 'practically acquired skills', through which work experience may be re-evaluated as being the equivalent of certain school qualifications.

\section{Self-fulfilling prophesies?}

Although the number of dropouts is decreasing slightly, the results are still unsatisfactory and it is unlikely that the target of halving the number of dropouts will be achieved. As a result of growing anxiety about migrant youth becoming criminals or radicalised, the disappointing effect of the existing policies has led to continued attention being given to measures to combat school dropout.

In this context, the policy discourses have resulted in these dropouts being presented along the following lines: in general, low educational achievement is considered to be the result of student-related deficits: the low educational level of parents, poverty, broken families, insufficient language use etc.. This explanation in terms of individual characteristics is further enhanced by stating that migrant youth, because of their cultural background, lack the competences required to adjust to and participate in the Dutch educational system, and also fail the modern requirements of self-development and social negotiation. Migrants are consequently portrayed as a 
high-risk group in need of special attention and care, particularly when it involves the group of non-participating young people who are seen as very problematic and are associated with 'undesirable behaviour' (SZW 2007). The consequence of this discourse may mean that young migrant people are blamed for their own disadvantage and that this contributes to the prevailing image of migrant people in the Netherlands as unwilling to integrate and adapt to Dutch society (Vasta, 2007). This may end up in the equation of ethnicity with failing skills, and may thus argue in favour of migrants being excluded without it being referred to as discrimination.

\section{Conclusion}

We wanted to know if forms of segmented assimilation could be detected in the Netherlands with drop-out figures of migrant youth as a marker. Our analysis of the dropout rates and the link between early school leaving and success or failure on the labour market shows that the general tendency for migrant youth is not necessarily downward. Although some migrant youngsters end up in unemployment because of their lack in educational qualifications, many others with the same background have found a position on the labour market. These findings are corroborated by other studies. For instance, there are signs of polarization among young second generation Turkish people in the Netherlands (Crul and Doomerik, 2003). On the one hand an increasing group of young Turkish people are successful in higher education and they form a cultural and political elite in their community. On the other hand, Turkish dropouts seem to reproduce the low-class position of their parents. This polarization can also be found among the Moroccan migrants (see Crul et al., 2008). This is a tendency also described by Faist (1995), referring to the position of Turkish 
young migrants in Germany where he sees a differentiation between successful school-leavers and those who do not enter the job training stage. Other migrant groups like the Surinamese are as a group faring better in education and employment. So polarization is not only taking place within the same migrant group but also between migrant groups. Furthermore the second generation migrants are clearly performing better than the first generation in terms of educational level and participation on the labour market. So, there is no overall prove to assume a segmented, downward assimilation of migrant youth.

We have shown furthermore that dropping out of school should not necessarily be seen as something dramatic, and the term dropout cannot, in fact, be used as a marker per se for downward mobility. The majority of dropouts can actually be considered to be less of a problem than imagined. They are in employment and have often even obtained an educational certificate. However, the fact is that the problematic group sets the image for the rest of the group. Discussions about early school leaving focus far too much on the dark side, and this means that early school leavers might possibly be stigmatized by the use of the term dropout.

The overview of figures and policies shows that the position of groups of young migrants in education is still, after numerous attempts to change their situation, unfavourable and is in need of improvement. Educational disadvantage, disproportionate dropout and unemployment levels, and discriminatory practices characterise their life chances in the Netherlands. This would seem to be the result of complex interaction between maladapted institutional methods to integrate migrants, and the migrants' own ways of situating themselves in Dutch society. It is especially important to point at the Dutch educational system as an institutional factor in distributing opportunities. The early selection for vocational or general secondary 
education works out as a disadvantage for migrant youth (Crul and Vermeulen, 2003), who because of still lesser performances in primary education are referred to vocational education. And within vocational education it is difficult for them to make the right choices for the labour market, which causes delay or disappointment and may enhance dropping out (SCP, 2008).

We think that these outcomes are interesting for reworking the theory of segmented assimilation. The presumed relation between early school leaving and reduced labour market opportunities, the phenomenon of, polarization between and in groups, and the specifics of the national contexts have to be dealt with in order to analyse more precisely the position of the second generation migrants.

It is however important to note that institutional barriers and policies targeting migrant youth as problematic contribute towards maintaining ethnic categorization. We have attempted to show how groups-at-risk are defined in the debate about dropout and unemployment, and how this process enhances the idea that disadvantage is linked to cultural and ethnic background. This implies a change in the social representation of second generation migrants. The problems of migrant youth, such as educational disadvantage, dropout or unemployment, are seen here in terms of a 'youth at risk' who is not capable of or even willing to participate in Dutch society. And because of a deliberate link between this incapacity/unwillingness and problems of harassment and criminality, the call for drastic measures is being heard ever more loudly. Problems of discrimination on the labour market, of changing qualifications, or of inadequate forms of education are only discussed in the margins. Living conditions in the urban conurbations, where highly segregated neighbourhoods are located, are mostly discussed as proof of unwillingness to mix 
and therefore to integrate. The troublemaking behaviour of some migrant youngsters in the inner cities is seen as illustrative of this refusal to adapt to Dutch society.

Discourses in the 1980s and 1990s were predominantly in terms of structural disadvantage that had to be overcome (SCP, 2006), whereas today the terms tend to be more cultural or ethnic in nature: the migrants' problems are related to their cultural or ethnic peculiarities and to the problems they have identifying with the norms and values of Dutch society. This redefinition implies that the Other i.e. migrants, fail to meet the social and cultural norms prevalent in the Netherlands, and that migrants are therefore responsible for their own exclusion. Problems of integration are attributed to migrants, and any reciprocity in the process is swiftly put aside. We hope that our discussion on the transition from school to work for migrant youth has opened the way to explore the dynamics of exclusion and participation, and to consider the importance of discursive constructions that may contribute to the creation of new forms of exclusion.

\section{References}

BERENSCHOT 2006 Prep camps. Onderzoek naar de haalbaarheid van prep camps en alternatieven, Utrecht: Berenschot

CBS 2005 Met een startkwalificatie betere kansen op de arbeidsmarkt, Sociaaleconomische Trends, $4^{\mathrm{e}}$ kwartaal -- 2007a Een op de twintig leerlingen voortijdig van school, Centraal Bureau voor de Statistiek Webmagazine, 3 april 2007 
-- 2007b Toename jongeren met startkwalificatie in stedelijke gebieden, Centraal Bureau voor de Statistiek Webmagazine 7 mei 2007

-- 2008 Jaarrapport Integratie 2008, Den Haag: Centraal Bureau voor de Statistiek CPB 2006 Voortijdig schoolverlaten in Nederland: omvang, beleid en resultaten, Den Haag: Centraal Planbureau

CRUL, MAURICE et al. 2008 De tweede generatie. Last of kansen voor de stad? Den Haag: IMES/NICIS

CRUL, MAURICE and VERMEULEN, HANS 2003 The second generation in Europe, International Migration Review, vol. 37, no. 4, pp. 965-986 CRUL, MAURICE, DOOMERNIK, JEROEN 2003 The Turkish and Moroccan Second Generation in the Netherlands Divergent Trends between and polarization within two groups. International Migration Review, vol. 37, no. 4, pp. 1039-1064 DEKKERS, HETTY AND CLAASSEN, ADRIE 2001 Dropouts disadvantaged by definition? A study of the perspective of very early school leavers, Studies in Educational Evaluation, vol. 27, pp. 341-345 EIMERS, TON 2006 Vroeg is nog niet voortijdig: naar een nieuwe beleidstheorie voortijdig schoolverlaten, Nijmegen: Kenniscentrum Beroepsonderwijs Arbeidsmarkt FAIST, THOMAS 1995 Social citizenship for whom? Young Turks in Germany and Mexican Americans in the United States, Aldershot, Avebury HERWEIJER, LEX 2006 Voortijdig schoolverlaten. Aantallen, knelpunten en risicogroepen, Justitiële Verkenningen, vol. 32, no. 6, pp. 22-38 HOUTKOOP, WILLEM (ED.) 2004 The value of the Dutch basic qualification, Amsterdam: Max Goote Centre KENNISCENTRUM D66 2005 Voorkomen van voortijdig schoolverlaten. De 
noodzaak van differentiatie en decentralisatie in het voortijd schoolverlaten beleid, Den Haag: Kenniscentrum D66

LEE, TRISH and BREEN, LAUREN 2007 Young perceptions and experiences of leaving high school early: an exploration, Journal of community \& applied Social Psychology, vol. 17, pp. 329-346

MIN. ALGEMENE ZAKEN 2007 Samenwerken samenleven: beleidsprogramma Kabinet Balkenende IV 2007-2001, Den Haag: Min. Algemene Zaken

MIN. OCW 2002 Voortijdig schoolverlaten in het middelbaar beroepsonderwijs,

Den Haag, Min. OCW

-- 2006 Samenvatting Education at a glance, Den Haag: Min. OCW

-- 2007a Factsheets voortijdig schoolverlaten, Den Haag: Min. OCW

-- 2007b Brief voortijdig schoolverlaten, Den Haag: Min. OCW

-- 2008 Cijfers 2006-2007 Voortijdig Schoolverlaten, Den Haag: Min. OCW

MIN. SZW 2006 Ontwikkeling arbeidsmarktpositie jongeren, Den Haag: Min. SZW MIN. SZW 2007 Reactie van het kabinet op het advies van de sociaal economische raad "Niet de afkomst maar de toekomst. Een betere positie voor allochtone jongeren op de arbeidsmarkt”, Den Haag: Min. SZW OECD 2008 Jobs for Youth. The Netherlands, Paris: OECD ONDERWIJSRAAD 2004 Tot hier en nu verder, Den Haag: Onderwijsraad PERLMAN, JOEL and WALDINGER, ROGER 1997 Second generation decline? Children of immigrants, past and present - a reconsideration, International Migration Review, vol. 31, pp. 893-922 PORTENGEN, RENZE and DEKKERS, HETTY 1998, Van dropout tot ambachtswerker. Een dieptestudie onder zeer voortijdig schoolverlaters, Nijmegen: ITS 
PORTES, ALEJANDRO and ZHOU, MIN 1993 The new second generation:

Segmented assimiliation and its variants, Annals of the American Academy of political and social sciences, 530, pp. 74-96

PORTES, ALEJANDRO et al 2005 Segmented assimilation on the ground : the new second generation in early adulthood, Journal of Ethnic and Racial Studies, vol. 28, no. 6 , pp. $1000-1040$

ROGGEBAND, CONNY and VLIEGENTHART, RENS 2007 Divergent framing: the public debate on migration in the Dutch parliament and media, 1995-2004, West European Politics, vol. 30, no. 3, pp. 524-548

RWI 2005 Startklaar: Voorstellen voor sluitende aanpak jongeren zonder diploma, Den Haag, Raad Voor Werk en Inkomen

RWI 2006 Hoger opgeleide allochtonen op weg naar werk: successen en belemmeringen. Den Haag: Raad voor Werk en Inkomen

SARDES 2006 De uitkomsten van de RMC analyse 2005, Utrecht: Sardes.

SCP 2006 Hoge (jeugd)werkloosheid onder etnische minderheden, Den Haag: SCP -- 2007a. De Sociale Staat van Nederland 2007, Den Haag: SCP

-- 2007b. Jaarrapport integratie 2007, Den Haag: SCP.

SCP/WODC/CBS 2005 Jaarrapport integratie 2005, Den Haag: SCP

SER, 2006, Niet de afkomst, maar de toekomst, Den Haag: SER

SILBERMAN ROXANE and ALBA, RICHARD and FOURNIER, IRÈNE 2007

Segmented assimilation in France? Discrimination in the labour market against the second generation, Journal of Ethnic and Racial Studies, vol. 30, no. 1, pp, 1-27

SLEEGERS, FLEUR 2007 In debat over Nederland, Amsterdam, Amsterdam:

University Press 
STEVENS, LUC 2006 'Nieuwe leren onontkoombaar, want oude leren vastgelopen, in: Thijs Jansen et al. (red.), De nieuwe schoolstrijd, Meppel: Boom, pp.94-99 TASKFORCE JEUGDWERKLOOSHEID 2006, Juist nu doorbijten. Advies aan het nieuwe kabinet, Den Haag: Taskforce jeugdwerkloosheid THOMPSON, MARC and CRUL, MAURICE 2007 The second generation in Europe and the United States: how is the Transatlantic debate relevant for further research on the European second generation? Journal of Ethnic and Migration Studies, vol. 33, no. 7, pp. 1025-1041

VASTA, ELLIE 2007 From ethnic minorities to ethnic majority policy: Multiculturalism and the shift to assimilationism in the Netherlands. Journal of Ethnic and Racial Studies, vol. 30, no. 5, pp. 713-740

WERF, GREETJE VAN DER 2006 Het nieuwe leren is een onverantwoord maatschappelijk experiment, in: T. Jansen, G. de Jong, A. Klink, (red.) De nieuwe schoolstrijd, Meppel: Boom pp 84-93

WRR 2008 Niemand houdt van ze..., Den Haag: WRR ZHOU MIN 1997 Segmented assimilation: issues, controversies and recent research on the new second generation, International Migration Review, vol. 31, no. 4, pp. $975-1008$

WILLIBRORD DE GRAAF is Associate Professor in the Department of Interdisciplinary Social Science at Utrecht University.

ADRESS: Dep. Interdisciplinary Social Science, Utrecht University, Utrecht, 3508TC, the Netherlands. Email: w.a.w.degraaf@uu.nl

KAJ VAN ZENDEREN is PhD student in the Department of Interdisciplinary Social Science at Utrecht University. 
ADRESS: Dep. Interdisciplinary Social Science, Utrecht University, Utrecht, 3508TC, the Netherlands. Email: w.a.w.degraaf@uu.nl 